\title{
U.S. Domestic Politics and International Monetary Fund Policy
}

\author{
J. Lawrence Broz \\ and \\ Michael Brewster Hawes \\ Department of Political Science \\ University of California, San Diego
}

August 23, 2004

Prepared for the $8^{\text {th }}$ Annual International Society for New Institutional Economics Conference (ISNIE), Tucson, AZ, September 30 - October 3, 2004. We presented an earlier draft at the Delegation to International Organization Conference, Del Mar, CA September 19-20, 2003. We thank participants for comments. We also thank William R. Clark, Erica Gould, Joseph Joyce, Devesh Kapur, Louis Pauley, Shanker Satyanath, Beth Simmons, and Michael Tierney for written suggestions, and Mark Farrales and Molly James for excellent research assistance. 
Paper Title: U.S. Domestic Politics and International Monetary Fund Policy

Abstract: We examine the political motivations that shape International Monetary Fund lending decisions. While we focus on the IMF's most powerful member - the United States - we abandon the typical "national interest" reasoning in favor of a micro-incentive approach that connects the motivations of U.S. officials at the Fund to domestic politics. We argue that private actors with stakes in IMF policy communicate their goals to members of Congress via the normal political channels - voting and campaign contributions. We test this part of the argument directly. We assume that Congress, by virtue of its formal authority to rule on nearly every aspect of U.S. participation in the IMF, commands the allegiance of U.S. officials at the Fund. Having established a link between private actors and Congress, and Congress and U.S. representatives at the Fund, we test to see if IMF lending decisions are consistent with private actors' interests. Our overall goal is to provide microfoundations for Fund decision-making. 


\section{Domestic Politics and International Monetary Fund Policy}

\section{Introduction}

Emerging market crises of the 1990s stimulated new interest in the political motivations that shape International Monetary Fund (IMF or Fund) lending decisions. ${ }^{1}$ We focus on the interests and influence of the IMF's most powerful member - the United States - and we ground our approach in U.S. domestic politics. We argue that American "money-center" banks comprise a key constituency for the IMF and lobby on its behalf. ${ }^{2}$ U.S. policymakers, in turn, use their influence at the Fund to ensure that countries in which American banks are highly exposed fall under the IMF's insurance umbrella. In short, we provide microfoundations for IMF lending and identify a possible source of moral hazard in the lobbying activities of U.S. banks.

We are not the first to identify money-center banks as an important constituency for the IMF. A radical "dependencista" version of the argument has been around since at least the 1970s and a more orthodox variant is currently circulating (Stiglitz 2002, Bhagwati 2002, Barro 1998, Soros 1998). ${ }^{3}$ In addition, Oatley and Yackee (2000) examine the extent to which the commercial bank bias exerts a systematic effect on IMF lending. Our novel approach is to leverage information from U.S. domestic politics to shed light on IMF decision-making.

Figure 1 depicts how we understand the "chain of delegation" in international financial policymaking. It begins with private individuals within a major member country like the United States, and ends with that country's delegate at the IMF. In order to provide micro-foundations to this remote and aggregate international organization, we assume that private actors (voters and

\footnotetext{
${ }^{1}$ See Thacker (1999), Vreeland (1999), Przeworski and Vreeland (2000), Oatley and Yackee (2000), Barro and Lee (2001), Bird and Rowlands (2001), Dreher and Vaubel (2001).

${ }^{2}$ Money-center banks specialize in wholesale and international banking and are located in financial centers like New York, Chicago, and San Francisco. Their clients include governments, corporations, and other banks. Citibank, J. P. Morgan Chase, and Bank of America fit the description.

${ }^{3}$ Bhagwati (2002: 8-9) speaks of a "Wall Street-Treasury complex."
} 
interest groups) are the "fundamental principals" of IMF policy. All other actors in the chain of delegated policymaking are agents of these private constituencies, albeit not perfect agents. We highlight the pecuniary interests of private individuals. And by establishing links between these actors and domestic politicians, and then between domestic politics and international decisionmaking, we are able to elucidate the micro-incentives that underpin the behavior of a complex and distant international organization.

To derive the interests of private actors with respect to IMF and its policies, we ask: who benefits and who loses from IMF policies? To address this issue, we look to the economics literature on international financial rescues, and to the distributional effects of economic globalization more generally. We develop an interest group argument relating to commercial bank stakes in IMF policy, and a constituency argument relating to the winners and losers of globalization. We then analyze voting in the U.S. House of Representatives on IMF quota increases to establish the links between private actors and domestic politicians.

Congress, however, does not directly influence the day-to-day operations of the IMF, as U.S. law has no standing with international organizations. ${ }^{4}$ To advance their goals, members of Congress must work through the executive branch, directing the Secretary of the Treasury and the U.S. Executive Director to the IMF to advance congressional goals. We largely ignore this part of the delegation scheme, but we do evaluate IMF outcomes to see if IMF behavior is consistent with our arguments about the domestic distributional effects of IMF policy. At this level, we employ a "revealed preferences" approach: we analyze IMF lending outcomes as if the institution's decision makers were pursuing the interests of private actors (e.g., money-center banks) within the United States.

\footnotetext{
${ }^{4}$ Unlike important issues, such as increasing the U.S quota contribution to the IMF, Congress does not directly oversee many aspects of IMF decision making, such as the country loan arrangements.
} 
Our results are encouraging. At the congressional level, we find that campaign contributions from money-center banks have a large and significant impact on the propensity of members to vote in favor of increasing the U.S. quota contribution to the IMF. We also find that members representing districts with greater proportions of net "winners" from economic globalization are more likely to favor increasing the IMF's resources. We anticipate the first result because IMF financial rescues provide insurance to private creditors, allowing banks to retain the gains from international lending while distributing losses, when they occur, to the public sector. We predict the second result because the IMF, in pursuing its mandate to protect the world economy from financial shocks, encourages globalization and its attendant distributional consequences.

At the IMF level, we find that the size of a loan to a country is positively and significantly related to the degree of money-center bank exposure in that country, controlling for other factors. An important implication of this result is that moral hazard in international finance is at least partly a function of the interests of private actors seeking to externalize the risks of cross-border lending.

The paper is organized as follows. In Section 2, we provide background on what the IMF does and how its officials reach decisions. We also illustrate shortcomings in the scholarly work on the IMF, particularly the lack of attention to individual incentives. In the next three sections, we address these flaws. Section 3 contains our arguments and evidentiary strategy. Section 4 is the empirical analysis of congressional roll call votes on IMF quota increases, and Section 5 explores the determinants of IMF lending. The final section is the conclusion, which discusses implications.

\section{Mandate and Organization of the IMF}


The International Monetary Fund was conceived in 1944 to support global trade and economic growth by ensuring stability in the international financial system. As part of this mission, the IMF provides financial assistance to countries facing balance-of-payments difficulties. ${ }^{5}$

The Fund's approach for providing financial assistance has two main components financing and conditionality - that jointly address the immediate payments crisis and the underlying factors that contributed to it. Access to and disbursement of Fund assistance is conditioned on the adoption and pursuit of economic and structural policy measures negotiated by the IMF with the recipient country. This "conditionality," usually takes the form of performance criteria (e.g., inflation and spending targets) and policy benchmarks (e.g. tax reform and privatization). The aim is to alleviate the underlying economic difficulty that led to balance of payments problems, as well as to ensure repayment to the Fund.

Member countries provide all funds used by the IMF, and join the organization by making a capital subscription or "quota" and agreeing to abide by rules set up by its charter, known as the Articles of Agreement. ${ }^{6}$ In total, these quotas account for 95.5 percent of the IMF's resources.

Quotas are doubly important because they also determine a country's voting power. Control of the IMF, therefore, is heavily weighted toward the larger countries. It takes a majority vote to change day-to-day policy (including the approval of country loan arrangements and mid-loan reviews), but major policy decisions, such as increasing quota size, amending the Articles of Agreement, or selling gold reserves, require an 85 percent special voting majority.

\footnotetext{
${ }^{5}$ When a country spends more abroad on goods and services than it receives, it incurs a current account deficit. Selling assets or borrowing can finance this shortfall, and involves a private capital inflow into the deficit country (a capital account surplus). But when private sources do not cover the current account deficit, the government must finance it through the sale of foreign exchange (official reserves of foreign currencies). This is referred to as a balance-of-payments deficit.

${ }^{6}$ Each country's quota is calculated by a formula reflecting the relative size of its economy, using various measures of output and trade.
} 
The United States, with a quota equal to 17.5 percent of the total, has virtual veto authority over these super majority policy votes. ${ }^{7}$ Moreover, the U.S. appears to maintain a virtual veto over the day-to-day business of the IMF, even though there is no formal super majority requirement for these decisions (see below).

Day-to-day decisions in the IMF are made by the Executive Board, which is composed of 24 members. Eight of these directors represent the largest quota-holders: the United States (17.5\%), Japan (6.3\%), Germany (6.1\%), France (5.1\%), the United Kingdom (5.1\%), Saudi Arabia (3.3\%), China (3.0\%), and Russia (2.8\%). The remaining 16 directors represent multimember constituencies and are elected by these, mostly regional, groupings of nations. ${ }^{8}$ The Executive Board is in "continuous session" in Washington, meeting as often as business requires. Meetings are devoted mainly to deciding on loan arrangements, policy, and surveillance issues (Van Houtven 2002: 14-15).

Formal votes are very rarely taken in the Executive Board. Rather, the Board's decision rule prescribes that "The Chairman shall ordinarily ascertain the sense of the meeting, in lieu of a formal vote." 9 In other words, the Chairman of the Executive Board (i.e., the Managing Director of the IMF) surmises whether a position is supported by executive directors having sufficient votes to carry the question if a vote were taken (Van Houtven 2002: 23). Thacker says the U.S. planners wanted this rule to "muffle the strong voice of U.S. power, which nevertheless was decisive" (1999: 42, fn 17). Whatever its origins, the procedure suggests a simple majority basis for Board decisions. Some analysts argue, however, that it approximates a super majority rule, empowering large members like the United States (Thacker 1999: 41-42, Kahler 1990). One

\footnotetext{
${ }^{7}$ In the past, the U.S. share of the quota (and thus its voting power) was even higher. In the early 1980 s, for example, the U.S. quota was $19.5 \%$ of the total.

${ }^{8}$ Although the IMF's other (larger) representative body, the Board of Governors, has ultimate authority, it normally only meets only once a year. Its members have largely delegated their powers to the Executive Board.

${ }^{9}$ Rule C-10 of the Fund's Rules and Regulations.
} 
reason offered is that managing directors rarely take positions opposed by the U.S. or a coalition of large states. ${ }^{10}$ Another reason offered is that members who speak out against the U.S. do so at their own peril, since the U.S. can veto favored programs in retaliation. Finally, a small number of large members can form coalitions to push through a position.

These rules and procedures give the U.S. and other major shareholding countries a strong influence over IMF lending decisions. We are interested in the political economy of these decisions, so we necessarily focus on the motivations and influence of the large shareholders in the Fund. The problem for social scientists is that the "sense of meeting" voting procedure makes it hard to discern influence by any individual member.

The standard approach is to infer motivations and influence from patterns of IMF lending ex post. Robert Barro and Jong-Wha Lee (2002) provide a careful application of this "revealed preferences" approach after hypothesizing a positive association between the size of a debtor country's loan from the IMF (scaled to GDP), and that country's "political and economic proximity" to the United States. ${ }^{11}$ Their results support their argument and echo similar findings by Thacker (1999).

While the "revealed preferences" is undoubtedly useful, we believe that there is still room for improvement. Under such an approach, for example, micro-incentives of decision makers are undefined. In accounts like this, IMF officials advance an aggregate goal - their home country's "national interest," whatever that is - instead of being motivated by individual incentives

\footnotetext{
${ }^{10}$ U.S. representatives have always been present at the top of the IMF hierarchy. Although no American has ever been Managing Director of the IMF (they have all been European), the very important position of Deputy Managing Director has been filled by an unbroken succession of Americans since the 1940s. (Because the Deputy Managing Director had so many responsibilities, the office was split into three positions in 1994. Since then, an American has always been "First" Deputy Managing Director.)

${ }^{11}$ Barro and Lee's proxy for "political proximity" is the fraction of times the U.S. and the country in question vote identically in the U.N. General Assembly. Their measure of "economic proximity" is the ratio of the country's bilateral trade with the U.S. to the country's GDP. Since the size of an IMF loan program is also affected by demand-side factors (the needs of the deficit country), the reduced-form equation contains a set of additional variables as controls.
} 
conditioned on the institutional environment. ${ }^{12}$ While there may in fact be personal benefits (costs) that accrue to executive directors that take positions favoring (opposing) allies and trading partners, these incentives are not identified ex ante. What are these costs and benefits? Does the domestic authority that appoints and monitors the executive director benefit from using the IMF to promote foreign policy goals? Is electoral support from domestic residents involved? Are campaign contributions from private actors part of the story?

\section{Approach and Argument}

We develop our argument from the bottom up. We begin by identifying the "fundamental principals" of the IMF and defining their interests. We argue that private actors within large shareholding countries like the United States are the IMF's fundamental principals. We define the interests of these actors in narrow pecuniary terms: the IMF's policies have distributional effects that give private actors stakes in what the organization does. We then move up the chain of delegation to an institutional level in which individual voting on Fund policy is formal and observable - the U.S. Congress. ${ }^{13}$ We assume that domestic legislators care about reelection and therefore take positions that reflect voter and interest group stakes in the policy. Our results suggest that legislators' positions are indeed shaped by the lobbying activity of money-center banks and other constituency goals.

We then move to the IMF level, where we expect U.S. representatives to advance the interests of American banks, among other things. Since we can't observe this influence directly, we analyze IMF lending as if the U.S. delegate was the dominant decision maker actively pursuing the interests of U.S. money-center banks. We find that the size of an IMF loan to a

\footnotetext{
${ }^{12}$ On the other extreme, public choice treatments imbue IMF decision makers with powerful bureaucratic incentives, such as remuneration, autonomy, and the desire to avoid failure. See Vaubel (1991) and Willett (2002).

${ }^{13}$ Some decisions that the Fund makes must be ratified by Congress (e.g., quota increases), which opens a window into the politics of the IMF.
} 
country is positively and significantly related to the degree of U.S. money-center bank exposure in that country, controlling for other factors.

\section{3a. Private Actors and the IMF}

Among organized private actors, the portion of the financial sector in the United States that invests in and lends to emerging market economies is a key beneficiary of IMF activities (Oatley and Yackee 2000). This is because IMF financial assistance, even if intended to help stabilize the international financial system, is a form of insurance for creditors and a source of "moral hazard." The idea is that private investors and lenders to developing countries over commit to emerging economies because of the expectation, based on previous experience, that the IMF will provide the foreign exchange liquidity that will allow them to exit the country in time of crisis and without bearing their full losses. ${ }^{14}$

IMF bailouts let private creditors retain the gains from international lending and distribute (part of) the losses to the public sector. When the IMF provides funds to a member government, that government often uses the IMF funds to repay private creditors (Bird 1996). Financial market participants are aware of this risk transfer. Demirguc-Kunt and Huizinga (1991) found that unanticipated increases in U.S. government financial commitments to the IMF caused the market capitalization of exposed U.S. money-center banks to increase. While moral hazard and the risk subsidy to private actors may be inevitable consequences of stabilizing financial markets (Rogoff 1999), we simply argue that creditors with assets in developing countries are among the most important beneficiaries of IMF policy. We therefore expect money-center banks to lobby in support of the IMF.

\footnotetext{
${ }^{14}$ The IMF encourages moral hazard - both with creditors and debtor nations - but there is a vigorous ongoing debate on the extent of the problem. See Dell'Ariccia, Schnabel, and Zettelmeyer (2002), Jeanne and Zettelmeyer (2001), Dreher and Vaubel (2001), and Lane and Phillips (2000). The International Financial Institutions Advisory Commission (the Meltzer Commission), which Congress chartered to evaluate and recommend U.S. policy toward the IMF after the Asian crisis, viewed moral hazard to be the most important problem in international finance.
} 
Other private actors are affected by IMF policies. Among unorganized constituencies (voters), the actors that gain and lose from having the IMF stabilize the world economy can be identified via international trade theory. Stolper and Samuelson (1941) and Mundell (1957) identified the winners and losers from economic globalization in terms of factors of production, such as high-skilled and low-skilled labor, from which factor owners derive their incomes. Owners of locally abundant factors tend to gain more than average from globalization, while owners of scarce factors tend to lose. In the United States, the relatively scarce factor is lowskilled labor, and thus the group most likely to lose from globalization is low-skilled labor (Wood 1994). ${ }^{15}$ By contrast, highly skilled labor is abundant in the U.S. relative to the rest of the world and thereby benefits from globalization. ${ }^{16}$

Our extension to IMF policy recognizes that the Fund's mandate to protect global trade and economic integration from financial disorder is a benefit to private actors that gain from integration. We thus expect people with high (low) skills to support (oppose) the IMF. Although these interests are diffuse, we expect to see them represented in the electoral calculations of legislators.

\section{3b. Congress and the IMF}

The IMF is a creature of Congress. Congress voted the institution into existence and it retains the authority to determine the terms of U.S. involvement in the organization. Although the President appoints the U.S. Executive Director, who then answers to the Secretary of the Treasury, the ultimate arbiter of U.S. participation in the IMF is the Congress.

\footnotetext{
${ }^{15}$ As trade has increased with nations where low-skilled labor is relatively abundant (and hence cheap), organized labor in the U.S. has mobilized against globalization, and received protection in less-skilled intensive industries in return (Haskel and Slaughter 2000; Baldwin and Magee, 2000).

${ }^{16}$ Existing individual-level data from public opinion surveys provide support for the argument. Scheve and Slaughter (2001) show that workers with college degrees or high skills support further liberalization of international trade while those with less education and fewer skills resist such initiatives.
} 
Over the years, legislators have tried to shape the agenda that U.S. appointees to the IMF must advance. By 2001, Congress had set 60 legislative mandates prescribing U.S. policy goals at the Fund (U.S. General Accounting Office 2001). These mandates cover a wide range of policies, including labor standards, international trade, human rights, and weapons proliferation. In every case, Congress directs the Secretary of the Treasury to instruct the U.S. Executive Director to use his or her "voice and vote" on the Executive Board of the Fund to pursue specific policies (Wertman 1998a). ${ }^{17}$ However, on major IMF policy changes, such as an increase in the U.S. quota contribution, Congress maintains direct authority.

Legislator positions are likely to be shaped by many factors, including partisan identity, political ideology, and expectations about the future consequences of IMF rescues (the moral hazard problem). However, we make the standard assumption that legislator behavior is selfinterested and derives from the desire to remain in office. This assumption implies that members of Congress make decisions on IMF policy based upon how these policies affect them electorally, without regard for the policies' national or international affects. The link to private actors involves both campaign contributions from organized groups, such as money center banks, and votes of citizens affected by the distributional impact of IMF policy, such as high-skilled workers.

\section{3c. IMF Policymakers and IMF Policy}

IMF decision-making procedures give the U.S. Executive Director extraordinary influence. The absence of roll call voting at the IMF, however, makes it impossible to directly observe U.S. positions. We cannot resolve this problem. What we can do is see if IMF decisions are consistent with the motivations we uncover at the level of domestic politics. Specifically, we

\footnotetext{
${ }^{17}$ As an international organization, the IMF is exempt from U.S. law, so Congress must work through the Secretary of the Treasury to affect IMF behavior.
} 
predict that the IMF will tend to give more support to countries in which American money-center banks have greater exposure. This assumes that the U.S. Executive Director and/or the Treasury Secretary are agents of these private actors. Scholars that see a "Wall Street connection" would have little difficulty with this assumption (e.g. Stiglitz 2002). However, it may also be the case that members of Congress, as agents of banking interests, or bankers themselves, communicate these policy goals to the Treasury Department. We make this second assumption, which is depicted in Figure 1.

\section{Data and Analysis: Congressional Roll Call Voting on IMF Quota Increases}

The IMF conducts a general review of the adequacy of quota resources at least once every five years. If it is determined that a quota increase is needed, member governments must first ratify the increase. Historically, these requests have been the occasion for rigorous congressional examinations of the IMF. Roll calls that occur during such debates in Congress provide a window into the politics of the IMF, and an opportunity to see if constituency pressures are involved.

We analyze congressional votes on the 1983 and 1998 requests for a quota increase. These were the only quota increases for which "clean" role call votes could be found. ${ }^{18}$ Table 1 provides summary information on the roll call votes we analyze. These four votes represent the universe of clean roll calls on IMF funding since 1973.

We have two hypotheses. First, we expect the probability a House member will vote in favor of the IMF quota call to increase with a member's affinity with money-center banks. This affinity is proxied by the amount of campaign contributions each member receives from money-

\footnotetext{
${ }^{18}$ Congress typically includes IMF funding in large omnibus spending bills, which makes it difficult to isolate legislator positions' on the IMF issue. However, we were able to identify amendments and motions to the 1983 and 1998 spending bills that dealt exclusively with IMF quota increases. These are "clean" votes, in the sense that a vote for or against captures a member's position on increasing U.S. contributions to the IMF.
} 
center banks. Second, we expect variation in skill levels across House districts to affect member voting. Specifically, we anticipate that the higher (lower) the skill level of constituents, the more likely a member will be to vote for (against) the IMF quota increase. This captures our argument that members see the IMF as an organization that promotes global economic integration, and take positions that reflect the impact of globalization on their constituencies.

To identify money-center banks, we use the regulatory classification in the Federal Financial Institutions Examination Council's (FFIEC) “Country Exposure Lending Survey.” Because the FFIEC survey identifies the specific banks that comprise the money-center group, we were able to obtain a list on which to base our collection of campaign contribution data. ${ }^{19}$ For campaign contributions, we use the Federal Election Commission's data on contributions from Political Action Committees (PACs). Our constructed variable is BANK_PAC: the sum total of money-center bank contributions to each House member, as a percentage of that member's total receipts. ${ }^{20}$

We measure constituent skill levels in two ways: by educational attainment and by occupational classification. COLLEGE is the share of district population with four years of college. SKILLS is the percentage of district workers in executive, administrative, managerial, professional, and professional specialty occupations. ${ }^{21}$

Table 2 presents results from Probit analyses of the three 1983 votes. In Models 1-3, we control only for member “ideology” as proxied by members' first dimension DW-NOMINATE score (Poole and Rosenthal 1997). We include this score to pick up some of the individual attributes that sway member voting. Since higher values denote a more "conservative" ideology

\footnotetext{
${ }^{19}$ See the Data Appendix for the banks that make up this group.

${ }^{20} \mathrm{We}$ thank a reviewer for suggesting this normalized specification. Alternate specifications of the variable - the amount of money-center bank contributions to each member, for example, or the share of members' total receipts that come from the financial industry in general - provide nearly identical results.

${ }^{21}$ See the Appendix A and B for variable descriptions, sources, and summary statistics.
} 
we expect, a positive sign: more economically conservative members should oppose increasing the quota because IMF bailouts create moral hazard. While we find evidence of this effect, our variables of interest, BANK_PAC and COLLEGE, are invariably correctly signed and highly significant. The more campaign contributions from banks and the higher the education level in a district, the more likely a member is to vote in favor of an IMF quota increase. In Model 4, we include controls for district INCOME (median household income) and MEXICAN ORIGINS (share of district population of Mexican ancestry). The latter control is intended to capture any effect that proximity to Mexico - the first victim of the debt crisis - might have on member voting. Our core results are not affected by the inclusion of these controls.

As a robustness check, we ran Probits using alternative measures of district skill level and member ideology. Table 3 contains results after substituting SKILLS (share of population working in high-skills industries) for college attainment, and adding PARTY ( $0=$ Dem, $1=\operatorname{Rep})$ to the DW-Nominate scores. Our findings are robust to these as well.

The vote on Obey's 1998 motion (V109, $105^{\text {th }}$ Congress) would seem to be a difficult one for our argument since members voted very strongly along party lines. Nevertheless our main variables are signed correctly (positive, since a "yes" vote would fund the IMF) and significant in several alternative models, as shown in Table 4. Model 1 controls for member ideology with DW-Nominate. Model 2 directly captures the partisan nature of the vote, and Model 3 adds variables that reflect potentially relevant district characteristics.

MEXICAN+KOREAN+THAI is the share of district population of ethnic groups originally from three countries that suffered major currency crisis in the 1990s. Our estimates do not support a relationship. NET IMPORTS and NET EXPORTS capture the effect of district industrial characteristics. Since the IMF pursues an essentially pro-trade mandate, members representing 
districts that face strong import competition are expected to oppose funding the IMF. Members with export-oriented industries in their districts, on the other hand, should support IMF funding. ${ }^{22}$ Our results are only suggestive, at best: the coefficients are correctly signed but not significant.

In Table 5, we provide a substantive interpretation of the results and a sense of the magnitude of the effects. Using models from Tables 2 and 4, we simulated the predicted probability of observing a vote in favor of increasing the IMF quota and then examined how these probabilities change as each explanatory variable is increased by one standard deviation above the mean. ${ }^{23}$ The effects are substantively large. For example, a one standard deviation increase in BANK_PAC increases the likelihood of support for IMF funding by as much as 19.9 percent (V286). The effects are smaller for the other votes, but never trivial. The average effect (across all models) of increasing campaign contributions by one standard deviation is to increase the probability of supporting the IMF by 13.4 percentage points.

We obtain similarly large substantive effects for COLLEGE, our measure of district skill levels. Increasing the share of district population with a college diploma by one standard deviation increases the probability a member will support IMF funding by 10.9 percent, on average. Note that the effects are quite large even where PARTY has an overwhelming impact on voting (V109, Model 2).

\section{4a. Discussion}

The positive relationship between money-center bank contributions and member support for the IMF clashes with research on contributions from special interests more generally: there is little evidence that campaign money influences member voting (Wright 1996, Snyder 1992, Hall and

\footnotetext{
${ }^{22}$ See the Appendix for the complicated construction of these variables.

${ }^{23}$ The simulations were performed with "Clarify" (Tomz et al 1998; King et al 2000).
} 
Wayman 1990). One possibility is that contributions from banks are different than money from other sources. For example, the banking industry is one of the largest contributors to member campaigns: commercial banks rank in the top ten in terms of total giving (PAC, individual, soft money) to Congress among over 80 industries (Makinson (2003). This may help explain why our study and others (Kroszner and Stratmann, 1998) find an effect of bank money on congressional roll call voting. ${ }^{24}$

A broader concern is whether special interests target members with similar positions or "buy votes" when they give contributions (Bronars and Lott, 1997; Hall and Wayman 1990). We are largely agnostic on the issue because it makes little difference to our argument whether banks give money to reward members or give money to sway their votes. Either way, the money is an observable indication of a relationship in which members are more likely to vote the way banks want.

What is clear is that money center banks target members with particular influence over banking and financial policy. Table 6 shows that the majority of the top twenty recipients of money-center bank contributions were members of the Committee on Banking, Finance, and Urban Affairs. It also shows that all but two of these members voted in favor of the 1983 IMF quota increase. This targeting of committee members may derive from the decentralized nature of congressional decision making: banks may understand that money allocated to the committee is more efficiently spent (Grier and Munger 1991). It may also reflect an understanding of the committee assignment process: banks are more likely to find a sympathetic audience in this committee (Shepsle 1978).

\footnotetext{
${ }^{24}$ It is also possible that our estimates on bank influence may be inflated due to some unmodeled constituency effect. We tested for this by adding a dummy variable for districts that were home to money-center banks (New York, Chicago, Boston, San Francisco), as well as a variable for the percentage of a district's population employed by large commercial banks. Neither variable proved significant, and neither variable affected the size and significance level of BANK_PAC.
} 
Our second major finding, that higher district skill levels increase the probability a member will support the IMF, is also open to alternative explanations. Our interpretation is that member positions on rescues reflect the relative wage effects of globalization on district constituencies. Perhaps the result could also be read as indicating that more educated constituents are more "cosmopolitan" and better equipped intellectually to understand the need for international financial rescues. But while a college education or a high skill occupation could give rise to an internationalist outlook, there is no compelling reason why these attributes imply support for rescues. Academic economists are divided on the issue, with a handful taking public stances against rescues on moral hazard grounds (Calomiris 1998, Meltzer 1998, Schwartz 1998). More education might make people more likely to support other foreign economic policies, like trade liberalization, where the overwhelming majority of academic opinion favors free trade. But on rescues, no such unanimity exists. Therefore it is difficult to attribute the results to constituents' intellectual capacity.

Our argument also requires that constituents and members of Congress understand the connections between IMF rescues and economic globalization, and between globalization and relative income shares. Do people really connect the dots that run from the IMF bailouts to domestic distributional consequences? Evidence from peak organizations, industry groups, and congressional testimony suggest they do. For example, organized labor connected the dots when the Executive Council of the AFL-CIO adopted a resolution in 1998 urging Congress to reject U.S. participation in the IMF unless borrowers adopted strict labor standards. Corporate organizations and export interests connect the dots by taking pro-IMF stances, as when the U.S. Chamber of Commerce included a Senate vote on IMF funding in its 1998 legislator ratings. Bernie Sanders also connected the dots: "What precedent is this [Asian] bailout setting, and 
what does it say about our role in the globalization of the international economy? If the U.S. Government cannot protect millions of workers, small business people, and family farmers in this country... should we really be responding to every bank and business failure throughout the world?",25

\section{IMF Lending Patterns}

We have established a relationship between money-center bank contributions and congressional voting on IMF issues. In this section, we check to see if money-center bank influence carries through to IMF policy decisions. Our findings suggest that IMF lending decisions are correlated with the size of U.S. commercial banks' loans outstanding in IMF member countries.

Two questions about IMF behavior motivate the analysis. First, does the extent of commercial bank exposure make the IMF more likely to bail out a country, should it face a currency or debt crisis? Second, does greater commercial bank exposure induce the IMF to provide larger loans to a country, all else equal? In order to examine these questions, we adopt a two-stage approach. In the first stage, we look solely at the decision by the IMF to offer assistance; in the second we examine the amount of assistance approved by the IMF. ${ }^{26}$

Our dataset spans twenty years (1983-2002) during which the IMF approved 369 loans under the Stand-By and Extended Fund Facilities (EFF) programs. In the first step of our analysis, our dependent variable is a binary variable, representing whether or not a member country received an IMF loan in a given year. In the second stage, we analyze the size of IMF loans approved for member countries (scaled to income).

\footnotetext{
${ }^{25}$ Bernard Sanders, "Let the Asian Tigers Fend for Themselves." Los Angeles Times, December 10, 1997.

${ }^{26}$ We treat the decision to lend as separate from the actual amount of assistance because of the potential for endogeneity: the decision to support a country may serve as a "seal of approval," inducing further lending from the private-sector.
} 
As our prior analysis focused on the ties between American money-center banks and the U.S. Congress, the chief explanatory variable for this part of the analysis is the country exposures of these same banks abroad. For reasons of confidentiality, individual banks do not disclose the geographic profile of their foreign loans. However, the Federal Financial Institutions Examination Council (FFIEC) collects, aggregates, and publishes this information for the group of money-center banks, in order to track overall lending behavior. Thus, our key independent variable is the amount owed to U.S. money-center banks by each IMF member country (US_BANKS). ${ }^{27}$ Since the U.S. is not the only major international lender with a strong voice in IMF decision-making, we also include the foreign lending behavior of major banks from England, France, Germany, and Japan. ${ }^{28}$

Our theory does not lead us to predict that increased private-sector bank lending will necessarily cause a country to require IMF assistance, but rather, that of those countries experiencing debt or currency crises in a given year, the IMF will be more likely to provide assistance to those with larger debts to banks in the Fund's top-five donor countries. Consequently, in order to predict IMF lending behavior, our model must include the principal variables used to predict and identify sovereign debt and currency crises in the first place.

Economists at the IMF and elsewhere have developed models of currency and debt crises in order to establish an Early-Warning-System (EWS) that can be used by the Fund in its surveillance of the world's economies. Kaminsky, Lizondo and Reinhart (1997) critically review EWS models and identify the economic indicators that yield the best predictive power. We draw from their conclusions and include several indicators related to countries' overall debt, debt

\footnotetext{
${ }^{27}$ These figures represent the total amount of loans by U.S. money center banks outstanding in the IMF member country. As there is significant annual variation in total money-center bank lending, while lending patterns to individual countries remain relatively constant, we have elected not to scale this variable as a percentage of the total banks' annual lending portfolio, instead opting for the more stable actual dollar amounts.

${ }^{28}$ Data are from the Bank for International Settlements.
} 
profile, international reserves, and overall economy. We also include an indicator of financial crises, generated by Caprio and Klingebiel (2003). Finally, since instability may persist beyond the duration of the Fund's assistance, we also include a dummy variable for countries that have received any Stand-By or EFF loans over the prior decade.

International politics may also affect IMF decision-making. We follow Barro and Lee (2002) and include UN affinity scores for debtor countries vis-à-vis the major powers, as well as changes in these scores from the prior year. ${ }^{29}$ Similarly, we include loans from the World Bank and International Development Association, on the grounds that IMF might be more willing to lend to countries that are receiving development assistance from the World Bank. ${ }^{30}$

\section{5a. Data and Analysis}

We expect greater commercial bank exposure to increase the likelihood of IMF assistance for countries in crises. To evaluate this claim, we ran a time-series cross-section Logit model of our binary dependent variable (did the member-country receive an IMF loan in a given year?) on our independent variables and controls. The results in Table 7 provide modest support for our argument. The baseline model includes all variables except UN affinity scores, our proxies for “international politics." Note that including UN affinity scores has little substantive effect on our results. In both models, the exposure of U.S. money center banks (US_BANKS) is positively and significantly related to the likelihood that the IMF will provide a loan to a country. Substantively, the estimate suggests that a one standard deviation increase in U.S. bank loan exposure (roughly $\$ 4$ billion) increases the probability of receiving an IMF loan by over 2 percent.

\footnotetext{
${ }^{29}$ Affinity scores for Germany are not included, as they are unavailable from the Gertzke and Jo dataset for the bulk of the time period being analyzed.

${ }^{30}$ A set of additional controls round out the model: year dummies, a time trend, and dummy variables for regions and economic groupings.
} 
When we consider the loan exposures of banks from Britain, France, Germany, and Japan, the results are less consistent. While the coefficient for German private bank loan exposure (GERMANY_BANKS) is positive and significant, those for Britain, France and Japan are negatively signed, but insignificant. Multicolinearity may partly explain this result. These four countries are all home to major international banks whose lending portfolios strongly reflect U.S. bank lending; correlations with U.S. lending range from $r=0.45$ to $r=0.60$. Despite this overlap, we include these other countries' lending exposures because it is unrealistic to assume that these countries do not affect IMF decisions.

Our second hypothesis relates to the size of IMF loans given to countries that receive Stand-By or EFF assistance. Since a major factor in the size of an IMF loan is the scope of the recipient country's economy, we have scaled both our dependent variable (IMF loans) and our key independent variables (each country's bank lending) to the recipient countries' GDP. Using the same economic indicators and control variables, we expected to see a positive relationship between the amount of U.S. (and other contributors') bank lending to a country and the size of the loan it receives from the IMF. ${ }^{31}$

The results in Table 8 suggest that commercial bank exposure is related to the amount of IMF support a country receives. According to this model, an increase in the size of U.S. lending (as a percent of GDP) of one standard deviation yields an increase in the IMF loan of approximately $2.6 \%$ of the recipient country's GDP. We obtained similar results for Japanese bank exposure. The regression results also seem to indicate that political factors may be influencing IMF lending decisions. Recipient countries that have a higher voting coincidence (US_UN_AFFINITY) with the United States in the UN General Assembly appear to be more

\footnotetext{
${ }^{31}$ As our cases are now limited to just those countries receiving IMF assistance, our sample size drops to 165.
} 
likely to receive larger IMF loans, while changes in countries' affinity scores with France (FRANCE_UN_AFFINITY) also seem to affect the size of the IMF assistance package.

\section{Conclusion}

Our foray into the political economy of the IMF helps resolve some issues but raises others. We began by identifying the private actors within large member countries that have pecuniary stakes in IMF activities. This step is often ignored in the study of international organizations even though such organizations are nearly always created and maintained through domestic legislation in powerful member states. We then established that the organized segment of this constituency, money-center banks, actively participates in domestic politics by supplying legislators with campaign finance. Judging from our strong empirical results, members of Congress appear, in turn, to be responsive to these appeals, as well as to the interests of unorganized groups benefited or harmed by the IMF's pro-globalization mandate. The final link in the causal chain was to analyze IMF outcomes. Although our results at this level provide some support for the argument that the IMF acts in ways that reflect the interests of money-center banks, our evidence is modest and indirect. We have no direct evidence showing that the U.S. Executive Director at the Fund is a dutiful agent of the U.S. Congress. We have no direct evidence that Congress compels the U.S. delegate to advance the interests of private international banks. In fact, we have completely ignored a level of delegation that is probably crucial to IMF outcomes: the delegation from Congress to the executive branch that gives the U.S. Treasury Security and the U.S. Executive Director the predominant authority on the day-to-day business of the Fund.

We justify our lack of attention to this agency relationship in the standard, unsatisfying way: one need not actually observe monitoring and punishment for principals to effectively control agents because foresightful agents anticipate the boundaries of acceptable action and stay 
within them. Maybe this is how the supposed "Wall Street connection" actually operates to promote the interests of the international investment community? We are certain only that more research is necessary.

Overall, our multilevel arguments and statistical tests provide some insight into the indirect and complex relationship between private actors and the IMF. This relationship begins with the distributional goals of private actors and moves to the domestic legislatures of powerful member governments via the electoral connection. However, on all but the most important IMF decisions (e.g. quota increases), national legislatures have no direct influence over policy. As an international organization, the IMF is not subject to domestic law. Therefore, legislatures like the U.S. Congress must work through their agents at the IMF to influence Fund policy. In researching this paper, we found dozens of U.S. laws formally requiring the U.S. Executive Director to use his "voice and vote" at the IMF to pursue congressional goals. Our sense of the anecdotal evidence is that the U.S. Executive Director has a good deal of flexibility in deciding how to interpret and implement these mandates. ${ }^{32}$ In short, our assumption that the U.S. Executive Director is a perfect agent of Congress is not very realistic. Yet even though this chain of delegation may be long and indirect, the evidence we found suggests that domestic actors influence international organizations' policy-making.

\footnotetext{
${ }^{32}$ Partly because of this flexibility, several House members have expressed concern that mandates have not been followed. The Executive Director, however, has testified in subcommittee that the Treasury "takes the law very seriously," and that congressional mandates have had some success in influencing IMF policy - such as in the case of the Heavily Indebted Poor Country (HPIC) Initiative. (See testimony of Karin Lissakers in "Review of the Operations of the International Monetary Fund," U.S. GPO 1998.)
} 


\section{References}

Ansolabehere, Stephen, John de Figueiredo, and James M. Snyder, Jr. 2003. "Why Is There So Little Money in U.S. Politics?” Journal of Economic Perspectives 17, 1 (Winter): 105-30.

Arnold, R. Douglas. 1992. The Logic of Congressional Action. New Haven: Yale University Press.

Bailey, Michael. 2001. "Quite Influence: The Representation of Diffuse Interests on Trade Policy, 1983- 1994.” Legislative Studies Quarterly (February): 45-80.

Baldwin, Robert E. and Christopher S. Magee. 2000. Congressional Trade Votes: From NAFTA Approval to Fast-Track Defeat. Washington DC: Institute for International Economics.

Barro, Robert J. and Jong-Wha Lee. 2002. "IMF Programs: Who is chosen and what are the effects?” NBER Working Paper 8951.

Barro, Robert. 1998. “The IMF Doesn't Put Out Fires, it Starts Them.” Business Week (7 December): 18.

Bird, Graham. 1996. "The International Monetary Fund and Developing Countries: A Review of the Evidence and Policy Options," International Organization 50 (Summer): 477-511.

Bird, Graham and Dane Rowlands. 2001. "IMF Lending: How Is It Affected by Economic, Political, and Institutional Factors?" Journal of Policy Reform 4 (3):243-270.

Bordo, Michael D. and Harold James. 2000. "The International Monetary Fund: Its Present Role in Historical Perspective." NBER Working Paper 7724 (June): 1-57

Calomiris, Charles W. 1998. "The IMF's Imprudent Role as Lender of Last Resort.” Cato Journal 17, 3 (Winter): 275-94.

Caprio, Gerard and Daniela Klingebiel (2003). "Episodes of Systemic and Borderline Financial Crises" World Bank Research Paper.

Dell'Ariccia, Giovanni, Isabel Schnabel, and Jeromin Zettelmeyer. 2002. "Moral Hazard and International Crisis Lending: A Test.” IMF Working Paper No. 181 (October): 1-53.

Denzau, Arthur and Michael Munger. 1986. "Legislators and Interest Groups: How Unorganized Interests Get Represented.” American Political Science Review 80, pp. 89-106.

Dreher, Axel and Roland Vaubel. 2001. "Does the IMF Cause Moral Hazard and Political Business Cycles? Evidence from Panel Data." Institut für Volkswirtschaftslehre und Statistik No. 598-01, Universität Mannheim.

Gold, Joseph. 1984. Legal and Institutional Aspects of the International Monetary System: Selected Essays. Vol. II. Washington, D.C.: International Monetary Fund.

Gould, Erica R. 2003. "Money Talks: Supplementary Financiers and International Monetary Fund Conditionality." International Organization 57 (3): 551-86.

Grier, Kevin B. and Michael C. Munger. 1991. "Committee Assignments, Constituent Preferences, and Campaign Contributions." Economic Inquiry 29 (1991): 24-43.

Grossman, Gene M. and Elhanan Helpman. 1994."Protection for Sale." American Economic Review 84, 4 (September):833-850.

Hall, Richard L. and Frank W. Wayman. 1990. "Buying Time: Moneyed Interests and the Mobilization of Bias in Congressional Committees." American Political Science Review 84: 797-820.

Haskel, Jonathan E. and Matthew J. Slaughter. 2000. Have Falling Tariffs and Transportation Costs Raised US Wage Inequality? NBER Working Paper 7539. Cambridge, MA: National Bureau of Economic Research.

Jeanne, Olivier, and Jeromin Zettelmeyer. 2001. "International Bailouts, Moral Hazard, and Conditionality," Economic Policy, Vol. 33 (October): 409-432. 
Kahler, Miles. 1990. "The United States and the International Monetary Fund.” In Margaret P. Karns and Karen A. Mingst, eds., The United States and Multilateral Institutions (Boston: Unwin Hyman).

King, Gary, Michael Tomz, and Jason Wittenberg. 2000. "Making the Most of Statistical Analyses: Improving Interpretation and Presentation." American Journal of Political Science 44, 2 (March): 341-55.

Kroszner, Randall S and Thomas Stratmann. 1998. "Interest-Group Competition and the Organization of Congress: Theory and Evidence from Financial Services' Political Action Committees," American Economic Review 88, 5: 1163-87.

Larosière, J. 1984. "Current Policies of the IMF: Fact and Fiction" IMF Survey January.

Locke, Mary. 2000. "Funding the IMF: The Debate in the U.S. Congress." Finance and Development 37, 3 (September).

Makinson, Larry. 2003. Open Secrets: The Encyclopedia of Congressional Money and Politics. http://www.opensecrets.org/

Meltzer, Allan H. 1998. “Asian Problems and The IMF.” Cato Journal 17, 3(Winter): 267-74.

Mundell, Robert A. 1957. "International Trade and Factor Mobility." American Economic Review 47 (June): 321-35.

Mussa, Michael and Miguel Savastano. 1999. "The IMF Approach to Economic Stabilization." In Ben S. Berncanke and Julio J. Rotemberg (eds.), NBER Macroeconomics Annual 1999, pp. 79-122. Cambridge, MA: MIT Press.

Oatley, Thomas and Jason Yackee. 2000. "Political Determinants of IMF Balance of Payments Lending: The Curse of Carabosse?" Mimeo. University of North Carolina at Chapel Hill.

Poole, Keith T. and Howard Rosenthal. 1997. Congress: A Political-Economic History of Roll Call Voting. New York: Oxford University Press.

Poole, Keith T., Howard Rosenthal, and Boris T. Shor. 2003. Voteview for Windows v3.0.3: Roll Call Displays of the U.S. Congress, 1789-1988. Available at http://voteview.gsia.cmu.edu.

Przeworski, Adam, and James R. Vreeland. 2000. "The Effect of IMF Programs on Economic Growth." Journal of Development Economics 62: 385-421.

Scheve, Kenneth F. and Matthew J. Slaughter. 2001. "What Determines Individual Trade-Policy Preferences?" Journal of International Economics (August) 54, 267-92.

Schwartz, Anna J. 1998. Time to Terminate the ESF and IMF. Cato Foreign Policy Briefing No. 48. Washington DC: The Cato Institute (August 26).

Shepsle, Kenneth A. 1978. The Giant Jigsaw Puzzle: Democratic Committee Assignments in the Modern House. Chicago: University of Chicago Press.

Soros, George. 1998. The Crisis of Global Capitalism: Open Society Endangered. New York: Public Affairs.

Snyder, James. 1992. "Long-term Investment in Politicians; Or, Give Early, Give Often." Journal of Law and Economics 35: 15-43.

Stolper, Wolfgang and Paul A. Samuelson. 1941. "Protection and Real Wages." Review of Economic Studies 9: 58-73.

Thacker, Strom. 1999. "The High Politics of IMF Lending," World Politics 52, 1 (Oct): 38-75.

Tomz, Michael, Jason Wittenberg, and Gary King. 1998. CLARIFY: Software forInterpreting and Presenting Statistical Results. Version 1.2. Cambridge MA: Harvard University.

U.S. Chamber of Commerce. 1998. How They Voted. Washington: Chamber of Commerce.

U.S. General Accounting Office. 2001. International Monetary Fund: Efforts to Advance U.S. Policies at the Fund. Report No. GAO-01-214 (Washington, D.C): 1-78. 
U.S. Government Printing Office. "Review of the Operations of the International Monetary Fund, Hearing before the Subcommittee on General Oversight and Investigations of the Committee on Banking and Financial Services." Serial No. 105-55. Washington: U.S. GPO, 1998.

Van Houtven, Leo. 2002. Governance of the IMF: Decision Making, Institutional Oversight, Transparency, and Accountability. IMF Pamphlet Series No. 53. Washington, D.C.:IMF.

Vaubel, Roland. 1991. "The Political Economy of the International Monetary Fund: A Public Choice Analysis." In Roland Vaubel and Thomas Willett, eds. The Political Economy of International Organizations. Boulder, CO: Westview Press, pp. 204-244.

Voeten, Erik (2001). Politics in the United Nations: Ideology, Institutions and Power in the Global Arena. PhD Dissertation, Princeton University.

Vreeland, James R. 1999. “The IMF: Lender of Last Resort or Scapegoat?" Prepared for the International Studies Association Conference, Washington, DC, February 16-21.

Wertman, Patricia A. 1998a. The IMF and 'Voice and Vote' Amendments: A Compilation. Congressional Research Service Report No. 98-391 (April 16):1-22.

Wertman, Patricia A. 1998b. The International Monetary Fund's (IMF) Proposed Quota Increase: Issues for Congress. Congressional Research Service Report No. 98-56.

Willett, Thomas D. 2002. "Towards a Broader Public Choice Analysis of the International Monetary Fund." Claremont McKenna College and Claremont Graduate University. Mimeo.

Wood, Adrian. 1994. North-South Trade, Employment, and Inequality: Changing Fortunes in a Skill-Driven World. Oxford: Clarendon Press.

Wright, John R. 1996. Interest Groups and Congress. Boston: Allyn and Bacon. 


\section{Figure 1: Chain of Delegation}

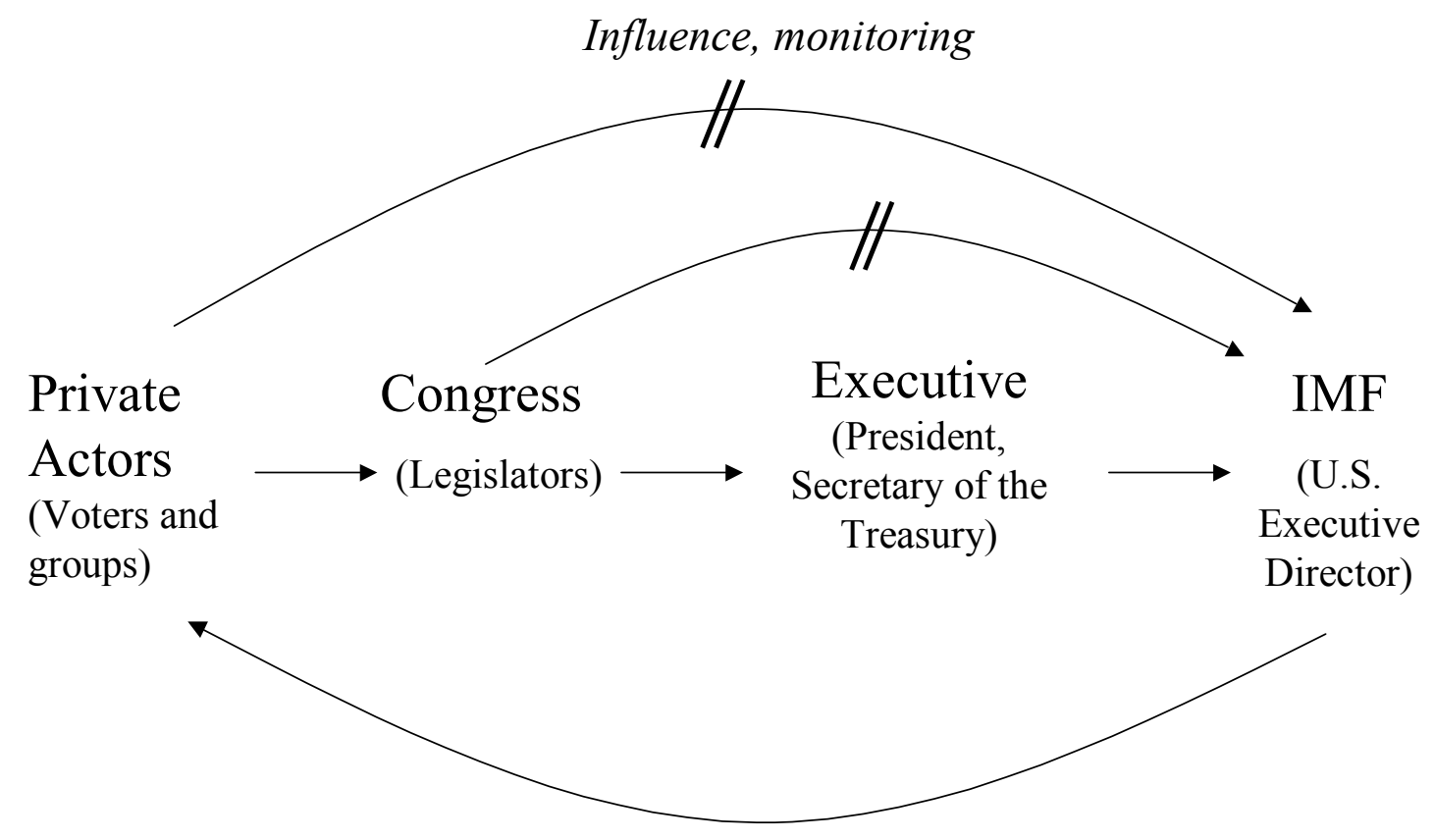

Distributional effects

Note: IMF policies have distributional effects on private actors in the United States but these actors do not directly influence IMF decision-making. Instead, they work through members of Congress to advance their pecuniary interests. Members of Congress, in turn, make sure their designated agents in the executive branch advance the goals of private actors. Private actors are thus the "fundamental principals" of the U.S. Executive Director to the IMF. 
Table 1: IMF Quota Votes in the U.S. Congress

\begin{tabular}{|c|c|c|c|c|}
\hline $\begin{array}{l}\text { Roll call } \\
\text { number }\end{array}$ & $\begin{array}{l}\text { V286 } \\
\text { H.AMDT. } 306 \\
\text { (HR 2957) }\end{array}$ & $\begin{array}{l}\text { V287 } \\
\text { H.AMDT. } 307 \\
\text { (HR 2957) }\end{array}$ & $\begin{array}{l}\text { V313 } \\
\text { H.AMDT.341 } \\
\text { (HR 2957) }\end{array}$ & $\begin{array}{l}\text { V109 } \\
\text { Motion to } \\
\text { Instruct } \\
\text { Conferees } \\
\text { (H R 3579) }\end{array}$ \\
\hline Congress & $98^{\text {th }}$ & $98^{\text {th }}$ & $98^{\text {th }}$ & $105^{\text {th }}$ \\
\hline Date & $7 / 29 / 1983$ & $7 / 29 / 1983$ & $8 / 3 / 1983$ & $4 / 23 / 1998$ \\
\hline Sponsor & McCollum (R-FL) & Patman (D-TX) & Corcoran (R-IL) & Obey (D-WI) \\
\hline $\begin{array}{l}\text { Summar } \\
\text { y }\end{array}$ & $\begin{array}{l}\text { To amend H.R. } 2957 \\
\text { to strike the } \\
\text { language authorizing } \\
\text { the Governor of the } \\
\text { IMF to consent to an } \\
\text { increase in the quota } \\
\text { of the United States. } \\
\text { [A "no" vote is a } \\
\text { vote in favor of the } \\
\text { IMF quota increase.] }\end{array}$ & $\begin{array}{l}\text { To amend H.R. } 2957 \\
\text { to eliminate } \\
\text { provisions in the bill } \\
\text { requiring continued } \\
\text { U.S. participation in } \\
\text { the IMF. } \\
\text { [A "no" vote is a } \\
\text { vote in favor of the } \\
\text { IMF quota increase.] }\end{array}$ & $\begin{array}{l}\text { To amend H.R. } 2957 \\
\text { to strike the } \\
\text { language that } \\
\text { increases U.S. } \\
\text { participation in the } \\
\text { IMF General } \\
\text { Arrangements to } \\
\text { Borrow from } \$ 2 \\
\text { billion to } \$ 4.25 \\
\text { billion, and } \\
\text { authorizes the } \\
\text { Secretary to consent } \\
\text { to an increase of the } \\
\text { U.S. quota in the } \\
\text { IMF. } \\
\text { [A "no" vote is a } \\
\text { vote in favor of the } \\
\text { IMF quota increase.] }\end{array}$ & $\begin{array}{l}\text { To allow the House } \\
\text { and Senate to pass } \\
\text { identical spending } \\
\text { bills, providing the } \\
\text { IMF with } \$ 18 \text { billion } \\
\text { for quota increase } \\
\text { and to establish the } \\
\text { New Arrangements } \\
\text { to Borrow (NAB). } \\
\text { [A "yes" vote is a } \\
\text { vote in favor of the } \\
\text { IMF quota increase.] }\end{array}$ \\
\hline Result & $\mathrm{Y}=182 \mathrm{~N}=227$ & $Y=178 \mathrm{~N}=226$ & $Y=174 \mathrm{~N}=249$ & $\mathrm{Y}=186 \mathrm{~N}=222$ \\
\hline $\begin{array}{l}\text { Partisan } \\
\text { split }\end{array}$ & $\begin{array}{l}\text { Dem: } Y=90, N=15 \\
8 \\
\text { Rep: } Y=92, N=69\end{array}$ & $\begin{array}{l}\text { Dem: } Y=89, N=15 \\
5 \\
\text { Rep: } Y=89, N=71\end{array}$ & $\begin{array}{l}\text { Dem: } Y=82, N=17 \\
7 \\
\text { Rep: } Y=92, N=72\end{array}$ & $\begin{array}{l}\text { Dem: } Y=164, N=2 \\
8 \\
\text { Rep: } Y=22, N=19 \\
3\end{array}$ \\
\hline
\end{tabular}


Table 2: Probit Analyses of IMF Quota Votes in the $98^{\text {th }}$ Congress

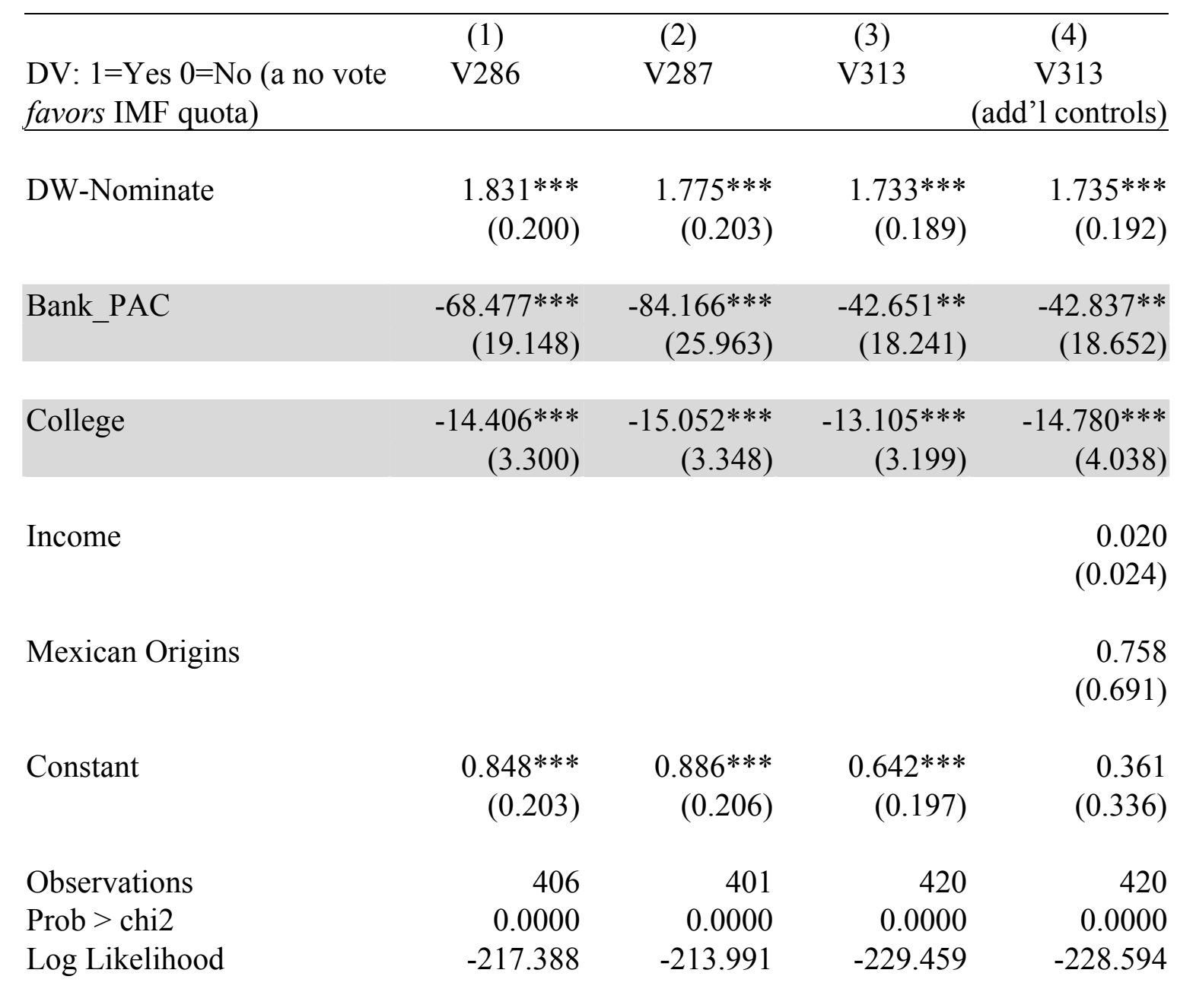

Robust standard errors in parentheses

$*$ significant at $10 \%$; ** significant at $5 \%$; *** significant at $1 \%$ 


\section{Table 3: Probit Analyses of IMF Quota Votes in the $98^{\text {th }}$ Congress (Robustness)}

\begin{tabular}{|c|c|c|c|c|}
\hline $\begin{array}{l}\text { DV: } 1=\text { Yes } 0=\text { No (a no vote } \\
\text { favors IMF quota) }\end{array}$ & $\begin{array}{c}(1) \\
\text { V286 }\end{array}$ & $\begin{array}{c}(2) \\
\text { V287 }\end{array}$ & $\begin{array}{c}(3) \\
\text { V313 }\end{array}$ & $\begin{array}{c}\text { (4) } \\
\text { V313 } \\
\text { (add'l controls) } \\
\end{array}$ \\
\hline DW-Nominate & $\begin{array}{r}4.112 * * * \\
(0.477)\end{array}$ & $\begin{array}{r}4.256 * * * \\
(0.498)\end{array}$ & $\begin{array}{r}3.224 * * * \\
(0.446)\end{array}$ & $\begin{array}{r}3.245 * * * \\
(0.454)\end{array}$ \\
\hline Party & $\begin{array}{r}-1.878 * * * \\
(0.316)\end{array}$ & $\begin{array}{r}-2.048 * * * \\
(0.324)\end{array}$ & $\begin{array}{r}-1.263 * * * \\
(0.294)\end{array}$ & $\begin{array}{r}-1.271 * * * \\
(0.302)\end{array}$ \\
\hline Bank_PAC & $\begin{array}{r}-58.983 * * * \\
(15.653)\end{array}$ & $\begin{array}{r}-74.272 * * * \\
(20.699)\end{array}$ & $\begin{array}{r}-38.513 * * \\
(16.116)\end{array}$ & $\begin{array}{r}-38.661 * * \\
(16.413)\end{array}$ \\
\hline Skills & $\begin{array}{r}-2.372 * * * \\
(0.842)\end{array}$ & $\begin{array}{r}-1.864 * * \\
(0.909)\end{array}$ & $\begin{array}{r}-2.209 * * * \\
(0.800)\end{array}$ & $\begin{array}{r}-2.246 * * * \\
(0.873)\end{array}$ \\
\hline Income & & & & $\begin{array}{r}0.007 \\
(0.023)\end{array}$ \\
\hline Mexican Origins & & & & $\begin{array}{r}0.903 \\
(0.728)\end{array}$ \\
\hline Constant & $\begin{array}{r}1.688 * * * \\
(0.316)\end{array}$ & $\begin{array}{r}1.594 * * * \\
(0.331)\end{array}$ & $\begin{array}{r}1.227 * * * \\
(0.291)\end{array}$ & $\begin{array}{r}1.088 * * * \\
(0.383)\end{array}$ \\
\hline $\begin{array}{l}\text { Observations } \\
\text { Prob > chi } 2 \\
\text { Log Likelihood }\end{array}$ & $\begin{array}{r}406 \\
0.0000 \\
-199.030\end{array}$ & $\begin{array}{r}401 \\
0.0000 \\
-195.812\end{array}$ & $\begin{array}{r}420 \\
0.0000 \\
-221.002\end{array}$ & $\begin{array}{r}420 \\
0.0000 \\
-220.257\end{array}$ \\
\hline
\end{tabular}

Robust standard errors in parentheses

$*$ significant at $10 \%$; ** significant at $5 \%$; *** significant at $1 \%$ 
Table 4: Probit Analyses of IMF Quota Vote in the $105^{\text {th }}$ Congress

\begin{tabular}{|c|c|c|c|}
\hline $\begin{array}{l}\text { DV: } 1=\text { Yes } 0=\text { No (a yes vote } \\
\text { favors IMF quota) }\end{array}$ & $\begin{array}{r}(1) \\
\text { V109 }\end{array}$ & $\begin{array}{r}(2) \\
\text { V109 }\end{array}$ & $\begin{array}{r}(3) \\
\text { V109 }\end{array}$ \\
\hline DW-Nominate & $\begin{array}{r}-2.682 * * * \\
(0.217)\end{array}$ & & $\begin{array}{r}-1.022 * * * \\
(0.397)\end{array}$ \\
\hline Party & & $\begin{array}{r}-2.533 * * * \\
(0.180)\end{array}$ & $\begin{array}{r}-1.726^{* * *} \\
(0.352)\end{array}$ \\
\hline Bank_PAC & $\begin{array}{r}20.614 * * * \\
(7.281)\end{array}$ & $\begin{array}{r}25.820 * * * \\
(8.247)\end{array}$ & $\begin{array}{r}24.505^{* * * *} \\
(8.194)\end{array}$ \\
\hline College & $\begin{array}{r}2.250^{* *} \\
(1.134)\end{array}$ & $\begin{array}{r}3.772 * * * \\
(1.137)\end{array}$ & $\begin{array}{r}3.121^{* *} \\
(1.242)\end{array}$ \\
\hline Net Imports & & & $\begin{array}{r}-1.472 \\
(1.128)\end{array}$ \\
\hline Net Exports & & & $\begin{array}{r}1.194 \\
(2.029)\end{array}$ \\
\hline Mexican+Korean+Thai & & & $\begin{array}{r}0.326 \\
(0.739)\end{array}$ \\
\hline Constant & $\begin{array}{r}-0.586^{* *} \\
(0.243)\end{array}$ & $\begin{array}{r}0.234 \\
(0.239)\end{array}$ & $\begin{array}{r}0.125 \\
(0.374)\end{array}$ \\
\hline Observations & 404 & 403 & 403 \\
\hline Prob $>$ chi 2 & 0.0000 & 0.0000 & 0.0000 \\
\hline Log Likelihood & -148.964 & -137.534 & -132.873 \\
\hline
\end{tabular}

Robust standard errors in parentheses

Note: By 1998, consolidations and takeovers had reduced the list of money-center banks to J.P. Morgan, Chase Manhattan, Bank of America, Citicorp, First Chicago and Bankers Trust. The contribution figures used for this table were calculated from the contributions of political action committees sponsored by these six remaining banks.

$*$ significant at $10 \% ; * *$ significant at $5 \% ; * * *$ significant at $1 \%$ 
Table 5: Substantive Effects of Campaign Contributions from Money-Center Banks, District Skill Levels, and House Member "Ideology"

\begin{tabular}{|c|c|c|c|c|}
\hline & Bank_PAC & College & DW-Nominate & Party \\
\hline $\begin{array}{l}\text { V286 (98 } \text { (9) }^{\text {th }} \text { Cong) } \\
\text { Table 2, Model } 1\end{array}$ & $0.171 * * *$ & $0.122 * * *$ & $-0.258 * * *$ & \\
\hline $\begin{array}{l}\text { V287 (98 } \text { (9) }^{\text {th }} \text { Cong) } \\
\text { Table 2, Model } 2\end{array}$ & $0.199 * * *$ & $0.126^{* * *}$ & $-0.254 * * *$ & \\
\hline $\begin{array}{l}\text { V313 (98 } \text { (9) }^{\text {th }} \text { Cong) } \\
\text { Table 2, Model } 3\end{array}$ & $0.108 * * *$ & $0.106^{* * *}$ & $-0.250 * * *$ & \\
\hline $\begin{array}{l}\text { V109 }\left(\mathbf{1 0 5}^{\text {th }} \text { Cong }\right) \\
\text { Table } 4 \text {, Model } 1\end{array}$ & $0.086^{* * *}$ & $0.073 * *$ & $-0.339 * * *$ & \\
\hline $\begin{array}{l}\text { V109 }\left(\mathbf{1 0 5}^{\text {th }} \text { Cong }\right) \\
\text { Table } 4 \text {, Model } 2\end{array}$ & $0.106^{* * *}$ & $0.120 * * *$ & & $-0.788 * * *$ \\
\hline
\end{tabular}

Note: Values represent the change in the predicted probability of voting in favor of an IMF quota increase ("no" on V286, V287, V313, and "yes" on V109) as each variable of interest is increased by one standard deviation over its mean, holding other variables at their means. "Party" indicates the change in predicted probability of moving from a Democrat to a Republican (from 1 to 0 ).

$* p<.10, * * p<.05, * * * p<.01$

Some tangible examples of the first differences, from the $98^{\text {th }}$ Congress:

\begin{tabular}{rll}
\hline & \multicolumn{1}{c}{ Mean } & Mean + 1 Std Dev \\
\hline Bank_PAC & 0.0026 (Pickle, TX-10) & 0.0096 (Derrick, SC-3) \\
College & 0.0569 (Chappell, FL-4) & 0.0795 (Kennelly, CT-1) \\
DW-Nominate & -0.0529 (Olin, VA-6) & 0.3179 (Bethune, AZ-2) \\
\hline
\end{tabular}


Table 6: Top 20 Recipients of Campaign Contributions from Money-Center Bank PACs, 1981-82 Election Cycle

Vote on IMF

Name State District Party Committee Bank_PAC V287

\begin{tabular}{|l|c|c|c|c|c|c|c|c|}
\hline LAFALCE, J & NY & 32 & Dem & Bank \& Fin & 0.0642 & No & No & No \\
\hline BARNARD, D & GA & 10 & Dem & Bank \& Fin & 0.0474 & No & No & No \\
\hline LUNDINE, S & NY & 34 & Dem & Bank \& Fin & 0.0463 & No & No & No \\
\hline ST GERMAIN & RI & 1 & Dem & Bank \& Fin (chair) & 0.0451 & No & No & No \\
\hline GREEN, S & NY & 15 & Rep & & 0.0333 & No & No & No \\
\hline HUBBARD, C & KY & 1 & Dem & Bank \& Fin & 0.0328 & No & No & No \\
\hline ANNUNZIO, F & IL & 11 & Dem & Bank \& Fin & 0.0324 &. & . & Yes \\
\hline WORTLEY, G & NY & 27 & Rep & Bank \& Fin & 0.0313 & No & No & No \\
\hline TOWNS, E & NY & 11 & Dem & & 0.0306 & No & No & No \\
\hline RIDGE, T & PA & 21 & Rep & Bank \& Fin & 0.0305 & No & No & No \\
\hline NEAL, S & NC & 5 & Dem & Bank \& Fin & 0.0297 & No & No & No \\
\hline WYLIE, C & OH & 15 & Rep & Bank \& Fin (ranking) & 0.0264 & No & No & No \\
\hline FISH, H & NY & 21 & Rep & & 0.0255 & No & No & No \\
\hline CARPER, T & DE & 1 & Dem & Bank \& Fin & 0.0199 & No & No & No \\
\hline ERDREICH, B & AL & 6 & Dem & Bank \& Fin & 0.0191 & Yes & Yes & Yes \\
\hline MCKINNEY & CT & 4 & Rep & Bank \& Fin & 0.0175 & No & No & No \\
\hline LEVIN, S & MI & 17 & Dem & Bank \& Fin & 0.0174 & No & No & No \\
\hline LEHMAN, R & CA & 18 & Dem & Bank \& Fin & 0.0144 & No & No & No \\
\hline ROUKEMA & NJ & 5 & Rep & Bank \& Fin & 0.0142 & No & No & No \\
\hline BEREUTER & NE & 1 & Rep & Bank \& Fin & 0.0140 & No & No & No \\
\hline
\end{tabular}

Notes: Bank_PAC is the sum of campaign contributions from money-center bank PACs in 1981 and 1982, as a percentage of total receipts for the 1981-1982 electoral cycle. The following bank PACs comprise the group: BankAmerica Federal Election Fund, Bankers Trust Corporation Fund for Good Government, Chase Manhattan Corporation Fund for Good Government, Chemical Bank Fund for Good Government, Citicorp Voluntary Political Federal Fund, Political Participation Fund of Continental Illinois, First Chicago Corp Government Affairs Associates, Manufacturers Hanover Corporation Association for Responsible Government, Morgan Companies Political Action Committee.

Bank \& Fin denotes a position on the House Committee on Banking, Finance, and Urban Affairs 
Table 7: Random Effects Logit Model of IMF Decisions to Lend

(1)

(2)

DV: IMF Decision to lend Baseline model Base with UN Affinity Scores $(1=$ Yes, $0=\mathrm{No})$

\begin{tabular}{|c|c|c|}
\hline US_Banks & $\begin{array}{l}.162 * \\
(.083)\end{array}$ & $\begin{array}{l}.164 * \\
(.090)\end{array}$ \\
\hline UK_Banks & $\begin{array}{l}-.128 \\
(.091)\end{array}$ & $\begin{array}{l}-.006 \\
(.100)\end{array}$ \\
\hline France_Banks & $\begin{array}{l}-.049 \\
(.122)\end{array}$ & $\begin{array}{c}.068 \\
(.142)\end{array}$ \\
\hline Germany_Banks & $\begin{array}{l}.352^{*} \\
(.104)\end{array}$ & $\begin{array}{l}.276^{* *} \\
(.110)\end{array}$ \\
\hline Japan_Banks & $\begin{array}{l}-.144 \\
(.097)\end{array}$ & $\begin{array}{l}-.064 \\
(.090)\end{array}$ \\
\hline Prior IMF loans & $\begin{array}{l}.890 * * \\
(.355)\end{array}$ & $\begin{array}{c}1.49 * * * \\
(.380)\end{array}$ \\
\hline Financing & $\begin{array}{l}.087 * \\
(.047)\end{array}$ & $\begin{array}{l}.038 \\
(.051)\end{array}$ \\
\hline IBRD loans & $\begin{array}{c}-2.5 \mathrm{e}-11 \\
(5.85 \mathrm{e}-11)\end{array}$ & $\begin{array}{c}9.10 \mathrm{e}-12 \\
(6.41 \mathrm{e}-11)\end{array}$ \\
\hline Short-Term Debt & $\begin{array}{c}-.034 * * * \\
(.013)\end{array}$ & $\begin{array}{c}-.050 * * * \\
(.016)\end{array}$ \\
\hline Reserves & $\begin{array}{c}2.29 \mathrm{e}-11 \\
(3.51 \mathrm{e}-11)\end{array}$ & $\begin{array}{c}2.89 \mathrm{e}-11 \\
(5.79 \mathrm{e}-11)\end{array}$ \\
\hline Debt & $\begin{array}{l}.051 \\
(.205)\end{array}$ & $\begin{array}{l}-.180 \\
(.192)\end{array}$ \\
\hline Money_Supply/Reserves & $\begin{array}{l}.013^{*} \\
(.008)\end{array}$ & $\begin{array}{l}.010 \\
(.007)\end{array}$ \\
\hline Trade & $\begin{array}{c}9.29 \mathrm{e}-3 * \\
(.005)\end{array}$ & $\begin{array}{l}.011^{* *} \\
(.005)\end{array}$ \\
\hline Debt_Service & & $\begin{array}{l}7 \mathrm{e}-12 \\
4 \mathrm{e}-11)\end{array}$ \\
\hline
\end{tabular}




\begin{tabular}{|c|c|c|}
\hline US_TBill & $\begin{array}{l}-.203 \\
(.219)\end{array}$ & $\begin{array}{l}-.218 \\
(.239)\end{array}$ \\
\hline GDPPC & $\begin{array}{c}-9.82 e-5 \\
(1.03 e-4)\end{array}$ & $\begin{array}{c}-1.75 \mathrm{e}-3 * \\
(1.0 \mathrm{e}-4)\end{array}$ \\
\hline Economic Crisis Dummy & $\begin{array}{l}.480 \\
(.262)\end{array}$ & $\begin{array}{c}.079 \\
(.302)\end{array}$ \\
\hline US Bank Total Lending & $\begin{array}{l}8.72 \mathrm{e}-6^{*} \\
(4.81 \mathrm{e}-6)\end{array}$ & $\begin{array}{l}1.64 e-5 \\
(1.5 e-5)\end{array}$ \\
\hline US_UN_Affinity & & $\begin{array}{l}-.405 \\
(2.43)\end{array}$ \\
\hline US_UN_Change & & $\begin{array}{l}4.51^{*} \\
(2.46)\end{array}$ \\
\hline UK_UN_Affinity & & $\begin{array}{l}-5.90 \\
(7.08)\end{array}$ \\
\hline UK_UN_Change & & $\begin{array}{l}-.297 \\
(6.1)\end{array}$ \\
\hline France_UN_Affinity & & $\begin{array}{c}5.62 \\
(7.50)\end{array}$ \\
\hline France_UN_Change & & $\begin{array}{l}-.657 \\
(5.93)\end{array}$ \\
\hline Japan_UN_Affinity & & $\begin{array}{c}7.01 \\
(4.59)\end{array}$ \\
\hline Japan_UN_Change & & $\begin{array}{c}1.95 \\
(3.87)\end{array}$ \\
\hline Observations & 931 & 654 \\
\hline Groups & 95 & 88 \\
\hline Log Likelihood & -376.97 & -247.9 \\
\hline
\end{tabular}

Standard errors in parentheses

* significant at $10 \%$;* significant at $5 \%$; ** significant at $1 \%$ 
Table 8: OLS Panel Estimates of the Size of IMF Loans

\begin{tabular}{|c|c|c|}
\hline $\begin{array}{l}\text { DV: Amount of IMF } \\
\text { loan, } \\
\text { scaled to recipient } \\
\text { country GDP }\end{array}$ & $\begin{array}{c}(1) \\
\text { Baseline } \\
\text { model }\end{array}$ & $\begin{array}{c}\text { (2) } \\
\text { Base with UN Affinity Scores }\end{array}$ \\
\hline US_Banks/GDP & $\begin{array}{l}.131 * * \\
(.050)\end{array}$ & $\begin{array}{l}.138 * * \\
(.061)\end{array}$ \\
\hline UK_Banks/GDP & $\begin{array}{l}1.51 \mathrm{e}-3 \\
(.014)\end{array}$ & $\begin{array}{c}-2.66 \mathrm{e}-3 \\
(.018)\end{array}$ \\
\hline France_Banks/GDP & $\begin{array}{l}-.047^{*} \\
(.028)\end{array}$ & $\begin{array}{l}-.013 \\
(.032)\end{array}$ \\
\hline Germany_Banks/GDP & $\begin{array}{l}6.34 \mathrm{e}-3 \\
(.028)\end{array}$ & $\begin{array}{l}.028 \\
(.033)\end{array}$ \\
\hline Japan_Banks/GDP & $\begin{array}{l}.023 * \\
(.013)\end{array}$ & $\begin{array}{l}.029 * \\
(.017)\end{array}$ \\
\hline Prior IMF Loans & $\begin{array}{l}8.26 \mathrm{e}-10 \\
(2.75 \mathrm{e}-9)\end{array}$ & $\begin{array}{c}2.2 \mathrm{e}-9 \\
(3.51 \mathrm{e}-9)\end{array}$ \\
\hline Financing & $\begin{array}{l}1.13 \mathrm{e}-9 * * \\
(4.53 \mathrm{e}-10)\end{array}$ & $\begin{array}{l}1.17 \mathrm{e}-9 * * \\
(5.59 \mathrm{e}-10)\end{array}$ \\
\hline IBRD & $\begin{array}{l}-5.77 \mathrm{e}-19 \\
(5.68 \mathrm{e}-19)\end{array}$ & $\begin{array}{l}-6.48 \mathrm{e}-19 \\
(7.06 \mathrm{e}-19)\end{array}$ \\
\hline Short-Term Debt & $\begin{array}{c}6.27 \mathrm{e}-11 \\
(9.40 \mathrm{e}-11)\end{array}$ & $\begin{array}{l}3.07 \mathrm{e}-10^{*} \\
(1.87 \mathrm{e}-10)\end{array}$ \\
\hline Reserves & $\begin{array}{l}4.80 \mathrm{e}-19 * \\
(2.89 \mathrm{e}-19)\end{array}$ & $\begin{array}{l}-7.94 \mathrm{e}-19 \\
(9.01 \mathrm{e}-19)\end{array}$ \\
\hline Debt & $\begin{array}{l}4.11 \mathrm{e}-10 \\
(1.48 \mathrm{e}-9)\end{array}$ & $\begin{array}{l}-2.29 \mathrm{e}-10 \\
(1.97 \mathrm{e}-9)\end{array}$ \\
\hline Money_Supply/Reserves & $\begin{array}{l}-9.76 \mathrm{e}-11 \\
(8.04 \mathrm{e}-11)\end{array}$ & $\begin{array}{l}-1.06 \mathrm{e}-10 \\
(7.89 \mathrm{e}-11)\end{array}$ \\
\hline Trade & $\begin{array}{c}2.82 \mathrm{e}-11 \\
(5.44 \mathrm{e}-11)\end{array}$ & $\begin{array}{l}-9.69 \mathrm{e}-11 \\
(7.48 \mathrm{e}-11)\end{array}$ \\
\hline
\end{tabular}




\begin{tabular}{|c|c|c|}
\hline Debt_Service & $\begin{array}{l}3.44 \mathrm{e}-19 * \\
(1.88 \mathrm{e}-19)\end{array}$ & $\begin{array}{c}4.55 \mathrm{e}-19 \\
(3.58 \mathrm{e}-19)\end{array}$ \\
\hline US_TBill & $\begin{array}{l}-2.34 \mathrm{e}-10 \\
(3.10 \mathrm{e}-9)\end{array}$ & $\begin{array}{c}2.49 \mathrm{e}-9 \\
(5.09 \mathrm{e}-9)\end{array}$ \\
\hline GDPPC & $\begin{array}{c}-2.69 \mathrm{e}- \\
12^{* *} \\
(1.27 \mathrm{e}-12)\end{array}$ & $\begin{array}{c}-3.66 \mathrm{e}-12 * * \\
(1.42 \mathrm{e}-12)\end{array}$ \\
\hline Economic Crisis Dummy & $\begin{array}{l}-1.03 e-11 \\
(2.09 \mathrm{e}-9)\end{array}$ & $\begin{array}{c}-4.81 \mathrm{e}-9 * \\
(2.67 \mathrm{e}-9)\end{array}$ \\
\hline US Bank Total Lending & $\begin{array}{l}6.50 \mathrm{e}-14 * \\
(3.84 \mathrm{e}-14)\end{array}$ & $\begin{array}{c}1.13 \mathrm{e}-13 \\
(1.32 \mathrm{e}-13)\end{array}$ \\
\hline US_UN_Affinity & & $\begin{array}{l}-3.87 \mathrm{e}-8 * \\
(2.34 \mathrm{e}-8)\end{array}$ \\
\hline US_UN_Change & & $\begin{array}{c}-2.17 \mathrm{e}-8 \\
(2.0 \mathrm{e}-8)\end{array}$ \\
\hline UK_UN_Affinity & & $\begin{array}{l}-2.42 \mathrm{e}-8 \\
(6.01 \mathrm{e}-8)\end{array}$ \\
\hline UK_UN_Change & & $\begin{array}{l}-8.10 \mathrm{e}-9 \\
(5.42 \mathrm{e}-8)\end{array}$ \\
\hline France_UN_Affinity & & $\begin{array}{c}1.08 \mathrm{e}-7 \\
(7.25 \mathrm{e}-8)\end{array}$ \\
\hline France_UN_Change & & $\begin{array}{l}1.11 \mathrm{e}-7 * * \\
(5.53 \mathrm{e}-8)\end{array}$ \\
\hline Japan_UN_Affinity & & $\begin{array}{l}-2.63 e-8 \\
(4.19 e-8)\end{array}$ \\
\hline Japan_UN_Change & & $\begin{array}{l}-9.74 e-9 \\
(4.19 e-8)\end{array}$ \\
\hline $\begin{array}{l}\text { Observations } \\
\text { Groups } \\
\text { Prob }>\text { Chi2 }\end{array}$ & $\begin{array}{c}165 \\
58 \\
0.07 \\
\end{array}$ & $\begin{array}{c}116 \\
50 \\
0.0016 \\
\end{array}$ \\
\hline
\end{tabular}

Standard errors in parentheses

$*$ significant at $10 \%$; * significant at $5 \% ; * * *$ significant at $1 \%$ 


\section{Appendix A: Data and Sources}

Party: $0=$ Democrat; $1=$ Republican.

DW-Nominate: The first dimension of the DW-Nominate score, which is interpreted as capturing a member's ideological position on government intervention in the economy. Higher values denote a more conservative ideology (McCarty, Poole, and Rosenthal 1997).

Bank PAC: Campaign contributions from money center bank political action committees to candidates in the previous electoral cycle, divided by the total receipts per candidate from the previous electoral cycle. Money-center banks are identified by the Federal Financial Institutions Examination Council, Country Exposure Lending Survey (various years). In 1983, the FFIEC list includes Bank of America, Bankers Trust, Chase Manhattan Bank, Chemical Bank, Citibank, Continental Illinois, First National Bank of Chicago, Manufacturers Hanover, and Morgan Guaranty. By 1998, consolidations and takeovers had reduced the list to: J. P. Morgan, Chase Manhattan, Bank of America, Citicorp, First Chicago, and Bankers Trust. PAC contributions are from the Federal Election Commission (http://www.tray.com).

College: Share of district population with four years of college (Congressional Districts of the United States, U.S., Bureau of the Census).

Skills: Share of district population aged 16 years and over employed in executive, administrative, managerial, and professional specialty occupations (Congressional Districts of the United States)

Income: Median household income (Congressional Districts of the United States).

Mexican Origins: Share of district population of Mexican ancestry (Congressional Districts of the United States).

Mexican+Korean+Thai: Share of district population of Mexican, Korean, and Thai ancestry (Congressional Districts of the United States).

Net Imports: Percent district population aged 16 years and over employed in net import industries. Net import industries are two-digit SIC manufacturing sectors where the ratio of imports to consumption is greater than the ratio of revenues from exports to total industry revenue (Textiles 22, Apparel 23, Lumber 24, Furniture 25, Paper 26, Petroleum 29, Rubber 30, Leather 31, Stone, Clay and Glass 32, Primary metals 33, Fabricated metals 34, Industrial machinery 35, Electronic goods 36, Transportation equipment 37, Other manufactures 39). County Business Patterns 1997 CD-ROM, Bureau of the Census. County-level employment data was aggregated up to the congressional district level using the following procedure: If a county contains more than one congressional district within its borders, the number of workers from an industry who are in each district is estimated by using the fraction of the county's population residing in each 
district. For example, if 10 percent of a county's population lives in a district, that district receives 10 percent of the county's workers in each industry. We obtained the geographic information from the MABLE '98/Geocorr v3.0 Geographic Correspondence Engine [http://plue.sedac.ciesin.org/plue/geocorr].

Net Exports: Percent district population aged 16 years and over employed in net export industries. Net export industries are two-digit SIC manufacturing sectors where the ratio of revenues from exports to total industry revenue is greater than the ratio of imports to consumption (Food 20, Tobacco 21, Printing 27, Chemicals 28, Instruments 38). See Net Imports and the text for the concordance procedure.

IMF Loans: Amount of IMF loans approved under the Stand-By and Extended Fund Facilities during the fiscal year, in millions of Special Drawing Rights (IMF Annual Reports 1983-2002)

US_Banks: Total amount owed U.S. money-center banks by foreign borrowers (excluding revaluations gains on foreign exchange and derivative products) as of March 31 of the reporting year. (Federal Financial Institutions Examination Council, Country Exposure Lending Survey)

Reserves: Changes in net reserves (BoP, current US\$). Changes in net reserves is the net change in a country's holdings of international reserves resulting from transactions on the current, capital, and financial accounts. These include changes in holdings of monetary gold, SDRs, foreign exchange assets, reserve position in the International Monetary Fund, and other claims on nonresidents that are available to the central authority. The measure is net of liabilities constituting foreign authorities' reserves, and counterpart items for valuation changes and exceptional financing items. Data are in current U.S. dollars. (World Development Indicators)

Money/Reserves: Money and quasi money (M2) to gross international reserves ratio. Money and quasi money comprise the sum of currency outside banks, demand deposits other than those of the central government, and the time, savings, and foreign currency deposits of resident sectors other than the central government. This definition is frequently called M2; it corresponds to lines 34 and 35 in the International Monetary Fund's (IMF) International Financial Statistics (IFS). Gross international reserves comprise holdings of monetary gold, special drawing rights, reserves of IMF members held by the IMF, and holdings of foreign exchange under the control of monetary authorities. The gold component of these reserves is valued at year-end (December 31) London prices. (World Development Indicators)

Trade: Trade (\% of GDP). Trade is the sum of exports and imports of goods and services measured as a share of gross domestic product. (World Development Indicators)

Financing: Financing from abroad ( $\%$ of GDP). Financing from abroad (obtained from nonresidents) refers to the means by which a government provides financial resources to cover a budget deficit or allocates financial resources arising from a budget surplus. It 
includes all government liabilities--other than those for currency issues or demand, time, or savings deposits with government--or claims on others held by government and changes in government holdings of cash and deposits. Government guarantees of the debt of others are excluded. Data are shown for central government only (World Development Indicators)

Debt: External debt, total current US\$). Total external debt is debt owed to nonresidents repayable in foreign currency, goods, or services. Total external debt is the sum of public, publicly guaranteed, and private non-guaranteed long-term debt, use of IMF credit, and short-term debt. Short-term debt includes all debt having an original maturity of one year or less and interest in arrears on long-term debt. Data are in current U.S. dollars. (World Development Indicators)

Short_Term_Debt: Short-term debt (\% of total external debt). Short-term debt includes all debt having an original maturity of one year or less and interest in arrears on long-term debt (World Development Indicators)

Debt_Service: Public and publicly guaranteed debt service (current US\$) Public and publicly guaranteed debt service is the sum of principal repayments and interest actually paid on long-term obligations of public debtors and long-term private obligations guaranteed by a public entity. Data are in current U.S. dollars. (World Development Indicators)

GDP: Gross Domestic Product (World Development Indicators)

GDPPC: Gross Domestic Product per capita (World Development Indicators)

US_TBill: nominal U.S. Treasury Bill rate (IMF, International Financial Statistics)

Prior IMF Loans: Dummy variable indicating whether or not the country received IMF assistance during the prior ten years. (IMF Annual Reports).

UK_Banks: Total foreign claims of UK banks on individual countries, in millions of U.S. dollars. (Bank for International Settlements, Consolidated Foreign Claims on Reporting Country Banks on Individual Countries.

France_Banks: Total foreign claims of French banks on individual countries, in millions of U.S. dollars. (BIS)

Germany_Banks: Total foreign claims of German banks on individual countries, in millions of U.S. dollars. (BIS)

Japan_Banks: Total foreign claims of Japanese banks on individual countries, in millions of U.S. dollars. (BIS) 
US Bank Total Lending: Total Amount owed U.S. money-center banks by foreign borrowers (excluding revaluations gains on foreign exchange and derivative products) as of March 31 of the reporting year. (Federal Financial Institutions Examination Council, Country Exposure Lending Survey)

IBRD: IBRD loans and IDA credits (current US\$) IBRD loans and IDA credits are extended by the World Bank Group. The International Bank for Reconstruction and Development (IBRD) lends at market rates. Credits from the International Development Association (IDA) are at concessional rates. Data are in current U.S. dollars. (World Development Indicators)

Economic Crisis Dummy: Dummy variable indicating whether or not the country experienced a systemic banking crisis during that year. (Caprio and Klingebiel)

US_UN_Affinity: Voting affinity score of countries relative to the U.S. position in the United Nations General Assembly. Voting affinity scores are measured on a -1 to 1 scale using Signorino and Ritter's "S" score, for three categories of voting behavior (with/abstain/against) A score of 1 indicates complete similarity of voting positions with the US, while a score of -1 indicates complete dissimilarity of voting. (Gertzke and Jo 2002)

US_UN_Change: Change in UN voting affinity score relative to the U.S. from the prior year (Gertzke and Jo 2002)

UK_UN_Affinity: Voting affinity score of countries relative to the British position in the United Nations General Assembly (Gertzke and Jo 2002)

UK_UN_Change: Change in UN voting affinity score relative to the British position from the prior year (Gertzke and Jo 2002)

France_UN_Affinity: Voting affinity score of countries relative to the French position in the United Nations General Assembly (Gertzke and Jo 2002)

France_UN_Change: Change in UN voting affinity score relative to the French position from the prior year (Gertzke and Jo 2002)

Japan_UN_Affinity: Voting affinity score of countries relative to the Japanese position in the United Nations General Assembly (Gertzke and Jo 2002)

Japan_UN_Change: Change in UN voting affinity score relative to the Japanese position from the prior year (Gertzke and Jo 2002)

Banking Centers: Dummy variable indicating countries that are considered to be major banking centers (FFIEC Country Exposure Lending Survey) 
Developed Countries: Dummy variable indicating countries that are highly developed economically (FFIEC Country Exposure Lending Survey)

Latin America: Regional dummy variable indicating Latin American countries (FFIEC Country Exposure Lending Survey)

Africa: Regional dummy variable indicating African countries (FFIEC Country Exposure Lending Survey)

Commonwealth: Dummy variable indicating countries that are members of the British Commonwealth (http://www.thecommonwealth.org/)

Francophonie: Dummy variable indicating countries that are members of the French "Francophonie" (http://www.francophonie.org/membres/etats/)

Year Trend: Time trend variable, in years, from 1983 to 2002 with 1983 equal to 1

\section{Appendix B: Summary Statistics}

Congressional Votes on Quota Increases

\begin{tabular}{|c|c|c|c|c|}
\hline & \multicolumn{4}{|c|}{ V286, V287, V313 (98 ${ }^{\text {th }}$ Cong) } \\
\hline & Mean & Std Dev & Min & $\operatorname{Max}$ \\
\hline DW-Nominate & -.0529 & .3707 & -.7780 & .9870 \\
\hline Party & .3839 & .4869 & 0 & 1 \\
\hline Bank_PAC & .0026 & .0070 & 0 & .0642 \\
\hline College & .0569 & .0226 & .0100 & .2075 \\
\hline Skills & .3534 & .0902 & .1450 & .8540 \\
\hline Income (\$1000s) & 16.915 & 3.560 & 7.154 & 28.181 \\
\hline \multirow[t]{2}{*}{ Mexican Origins } & .0393 & .0891 & .0007 & .7156 \\
\hline & \multicolumn{4}{|c|}{ V109 $\left(105^{\text {th }}\right.$ Cong) } \\
\hline & Mean & Std Dev & Min & $\operatorname{Max}$ \\
\hline DW-Nominate & .0645 & .4637 & -.7600 & 1.150 \\
\hline Party & .4747 & .4999 & 0 & 1 \\
\hline Bank_PAC & .0044 & .0098 & 0 & .0967 \\
\hline College & .2007 & .0799 & .0530 & .5138 \\
\hline Skills & .2584 & .0634 & .0918 & .5282 \\
\hline Mexican+Korean+Thai & .0581 & .1154 & .0013 & .7057 \\
\hline Net Imports & .1353 & .0801 & .0085 & .4263 \\
\hline Net Exports & .0536 & .0452 & .0002 & .4606 \\
\hline
\end{tabular}


Summary Statistics: IMF Lending Decisions

\begin{tabular}{|l|rrrr|}
\hline & \multicolumn{4}{|c|}{ IMF Lending Variables } \\
\hline \hline & \multicolumn{1}{|c}{ Mean } & Std Dev & \multicolumn{1}{c|}{ Min } & \multicolumn{1}{c|}{ Max } \\
Debt (log) & 21.73 & 1.99 & 14.40 & 26.22 \\
Debt Service & $1.68 \mathrm{E}+09$ & $4.80 \mathrm{E}+09$ & $0.00 \mathrm{E}+00$ & $7.11 \mathrm{E}+10$ \\
Economic Crisis Dummy & 0.16 & 0.36 & 0.00 & 1.00 \\
Financing & 1.38 & 2.68 & -9.30 & 21.34 \\
France Banks (log) & 3.56 & 3.02 & 0.00 & 12.40 \\
France Banks / GDP & $5.20 \mathrm{E}-08$ & $3.49 \mathrm{E}-07$ & 0.00 & $8.41 \mathrm{E}-06$ \\
France UN Affinity & 0.27 & 0.26 & -0.67 & 1.00 \\
France_UN Change & 0.01 & 0.16 & -0.90 & 1.33 \\
GDPPC & 5732.93 & 9238.23 & 49.32 & 56381.98 \\
Germany Banks (log) & 3.11 & 3.30 & 0.00 & 13.10 \\
Germany Banks / GDP & $6.75 \mathrm{E}-08$ & $7.45 \mathrm{E}-07$ & 0.00 & $1.88 \mathrm{E}-05$ \\
IBRD & $1.14 \mathrm{E}+09$ & $2.73 \mathrm{E}+09$ & 0.00 & $2.88 \mathrm{E}+10$ \\
IMF Loans / GDP & $1.94 \mathrm{E}-09$ & $1.49 \mathrm{E}-08$ & 0.00 & $7.3 \mathrm{E}-07$ \\
IMF Loans Dummy & 0.14 & 0.35 & 0.00 & 1.00 \\
Japan Banks (log) & 2.40 & 3.32 & 0.00 & 13.15 \\
Japan Banks / GDP & $9.40 \mathrm{E}-08$ & $1.03 \mathrm{E}-06$ & 0.00 & $2.76 \mathrm{E}-05$ \\
Japan UN Affinity & 0.47 & 0.21 & -0.50 & 1.00 \\
Japan UN Change & 0.01 & 0.14 & -0.87 & 1.33 \\
Money/Reserves & 13.68 & 80.57 & -68.37 & 2379.07 \\
Prior IMF Loans & 0.41 & 0.49 & 0.00 & 1.00 \\
Reserves & $-1.33 \mathrm{E}+08$ & $5.84 \mathrm{E}+09$ & $-5.98 \mathrm{E}+10$ & $9.69 \mathrm{E}+10$ \\
Short Term Debt & 13.30 & 13.43 & 0.00 & 91.88 \\
Trade & 77.47 & 44.42 & 1.53 & 361.18 \\
UK Banks (log) & 2.85 & 3.18 & 0.00 & 12.96 \\
UK Banks / GDP & $3.77 \mathrm{E}-08$ & $2.87 \mathrm{E}-07$ & 0.00 & $8.17 \mathrm{E}-06$ \\
UK UN Affinity & 0.23 & 0.30 & -0.88 & 1.00 \\
UK UN Change & 0.01 & 0.17 & -0.97 & 1.33 \\
US Banks (log) & 2.65 & 3.29 & 0.00 & 11.06 \\
US Banks / GDP & $1.64 \mathrm{E}-08$ & $1.12 \mathrm{E}-07$ & 0.00 & $3.49 \mathrm{E}-06$ \\
US Banks Total Lending & $2.06 \mathrm{E}+05$ & $7.18 \mathrm{E}+04$ & $1.23 \mathrm{E}+05$ & $3.65 \mathrm{E}+05$ \\
US T-Bill & 5.59 & 1.93 & 1.61 & 9.39 \\
US UN Affinity & 0.01 & 0.40 & -1.00 & 1.00 \\
US UN Change & 0.00 & 0.18 & -1.28 & 1.43 \\
\hline
\end{tabular}

